\title{
CURRENT STATE OF COENOPOPULATIONS OF SOME RARE ENDEMIC SPECIES IN NAVOI REGION, UZBEKISTAN
}

\author{
TASHKHANIM RAKHIMOVA ${ }^{1}$, NODIRA RAKHIMOVA $\otimes^{1}$, VASILA SHARIPOVA ${ }^{1}$, NATALYA BESHKO르. HAYITOV \\ RIZAMAT $^{2}$
}

${ }^{1}$ Institute of Botany Academy of Sciences Republic of Uzbekistan, Tashkent, 100125, Uzbekistan; e-mail: rakhimovanodi@mail.ru

${ }^{2}$ Navoi State Pedagogical Institute Str Ibn Sina, Navoi 210100, Uzbekistan

$\triangle$ Corresponding author

Received: 17 December 2020 / Accepted: 5 April 2021

\begin{abstract}
Rakhimova T., Rakhimova N., Sharipova V., Beshko N., Rizamat H.: Current state of coenopopulations of some rare endemic species in Navoi region, Uzbekistan. Ekológia (Bratislava), Vol. 40. No. 4, p. 357-363, 2021.

The problem of preserving the biological diversity of the Earth is attracting increasing attention of the world scientific community. Rare plant species, as the most vulnerable part of the flora, are under the greatest threat of extinction. In the study of this group of plants, population methods are increasingly being used. Revealing the number, structure, efficiency of self-renewal and resistance of populations of rare plants in relation to anthropogenic influences creates the basis for developing effective measures for their protection. The aim of the study was to assess the current state of coenopopulations of some rare endemic species - Acantholimon nuratavicum Zakirov ex Lincz. (Plumbaginaceae), Cousinia pseudolanata Popov ex Tscherneva (Asteraceae), Lepidolopha nuratavica Krasch. (Asteraceae) included in the Red Book of Uzbekistan. The results showed that in the ecological-coenotic conditions of the Navoi region, the studied coenopopulations are normal and incomplete. Ontogenetic spectra of coenopopulations are centred and left sided, with a peak for middle-aged and young generative individuals, which is associated with the ecological conditions of habitation and anthropogenic pressure.
\end{abstract}

Key words: biodiversity, cadastre, endemic, community, ontogenetic structure, coenopopulation.

\section{Introduction}

Today, one-third of the plant diversity is at risk of extinction. In recent years, many species have not been found in the course of field research and it is possible that these species have already disappeared. The number of species that are widely used in the national economy is small; but on the other hand, many species play a key role in natural ecosystems and serve to ensure their stability. Also, rare species, rarely used by the people, may be useful in the future. The population status of $94 \%$ of the world's plant species has not yet been assessed (Corlett, 2016).

In order to preserve the natural population of endangered species, the so-called 'plant species with extremely small population', large-scale work is underway in China. These studies include three stages: assessment of the natural state of populations of the species, introduction in botanical gardens or other protected areas and reintroduction of individuals into nature. The flora of China occupies the leading position in the richness of species in the world, but many of them are threatened with extinction. Despite tremendous efforts to conserve biodiversity over the past decade in China, many species with extremely small populations are still threatened with extinction (Volis et al., 2015).
Scientists from many scientific institutions of the world are engaged in research aimed at assessing the current state of populations of certain groups of plants, their preservation in situ, ex situ, quasi in situ, ensuring the stability of populations of rare species, forming a list of vulnerable species and developing measures for protecting their populations (Yang, 2013; Li, Zhang, 2015). Today, along with systematic, genetic, molecular studies, population studies are carried out at the world level. Publications devoted to the problems of preserving populations of rare and endangered plant species can be seen in highly rated international journals (Shomurodov, Khasanov, 2014; Shomurodov, Adilov, 2019; Rakhimova et al., 2020; Esanov, Sharipova, 2020; Klimantová, 2020; Bastian et al., 2020).

To assess the current state of populations of rare and endangered species, the most optimal method of our time is the coenopopulation (CP) approach based on the analysis of population and organismic characteristics of individuals. Such studies are widely used in Russia, Belarus and Ukraine in the Baltic countries, including Central Asia. An example of this is the research of V. A. Cheremushkina and A. Yu. Astashenkov on the assessment of the state of the populations of Nepeta podostachys Benth. in Tajikistan (Cheryomushkina, Astashenkov, 2014). The same authors carried out research in this area in different ecological and phytocenotic

(c) The Author(s) 2021. This is an open access article distributed under the terms of the CC BY-NC-ND license.

https://content.sciendo.com/view/journals/eko/eko-overview.xml 


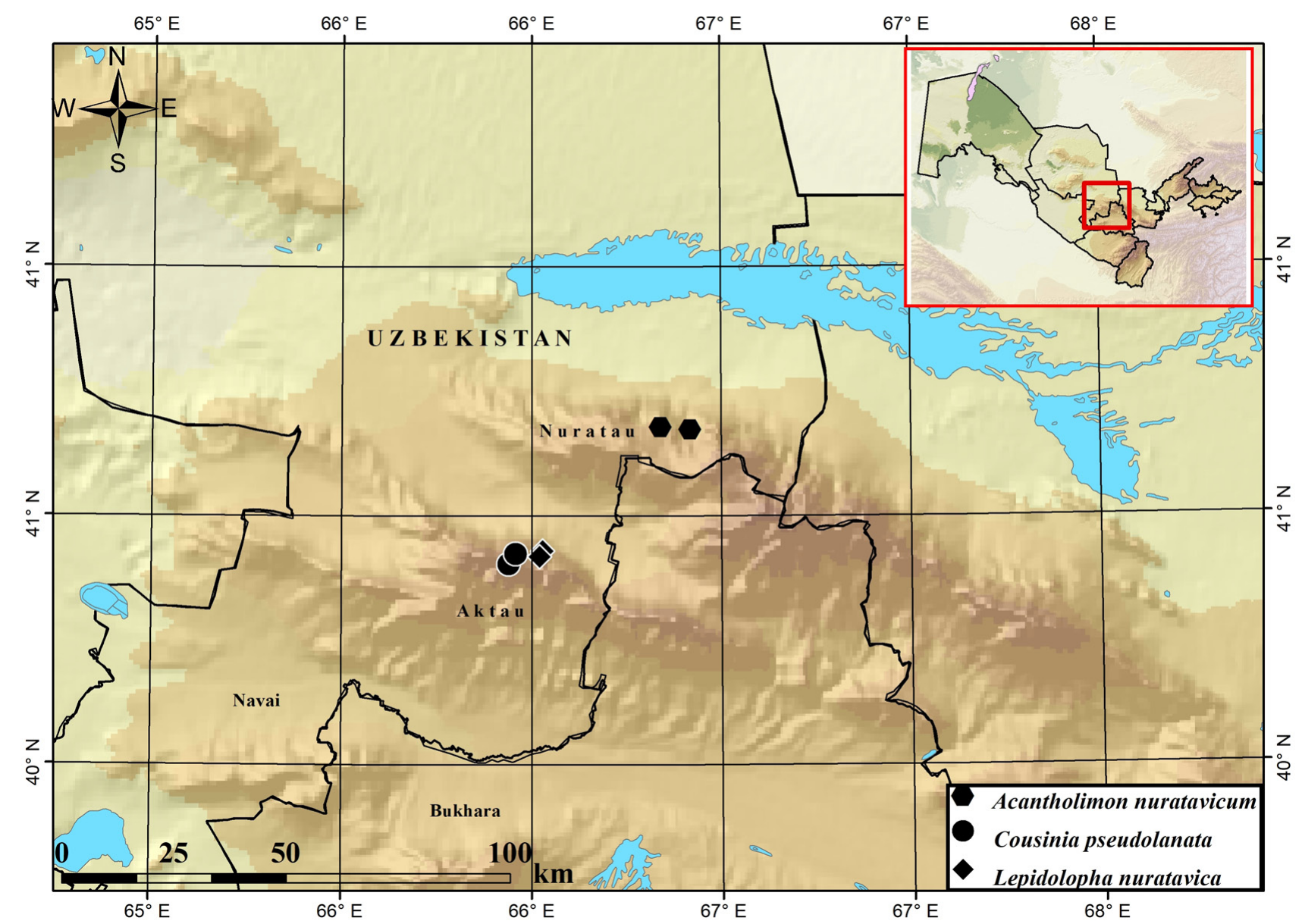

Fig. 1. Map of distribution of the studied species in the territory of Navoi region, Uzbekistan.

conditions of Siberia. The features of ontomorphogenesis and ontogenetic structure of six CPs of Dracocephalum grandiflorum L. were studied. The types of ontogenetic spectrum and its relationship with the features of the development of individuals in ontogenesis were revealed (Denisova, Cheremushkina, 2009).

Many scientific studies of Bashkortostan scientists have been devoted to the current state of coenotic populations of rare and endangered plants (Ishbirdin, Ishmuratova, 2009). They carry out comprehensive research with more than 40 rare and endangered species of flora of the Republic of Bashkortostan (they study the distribution of species, ontogenesis, demography and population dynamics, antecology, introduction, development of technologies for clonal micro-reproduction, etc.). The result of research in traditional and new directions is the description of the life strategy of the species and the development on this basis of measures and methods for protecting its populations. The study of rare and endemic species is one of the priority tasks in the field of botany, which is associated with the increasing relevance and significance of the problem of studying and preserving biological diversity. The most promising method for studying rare and endemic plant species is the study of their natural populations. In this regard, in Uzbekistan systematic studies to assess the state of populations of rare and endangered species using $\mathrm{CP}$ approaches began in the not-too-distant past. Since 2012, the staff of Insti- tute of Botany the Academy of Sciences Republic of Uzbekistan have been conducting research to assess the state of coenotic populations of rare and endangered plant species included in the Red Book of Uzbekistan. Based on the results of these studies, a number of articles have been published (Akhmedov et al., 2015; Shomurodov et al., 2015, 2017; Saribaeva, Shomurodov, 2017).

\section{Material and methods}

The objects of the study were rare and endangered species found in the Navoi region: Acantholimon nuratavicum Zakirov ex Lincz., Cousinia pseudolanata Popov ex Tscherneva and Lepidolopha nuratavica Krasch., included in the Red Book of Uzbekistan.

Geobotanical descriptions of plant communities, in which the studied species were identified, were made according to the generally accepted method (Field Geobotany, 1964). Latin names of plant species are given according to the latest summary by S. K. Czerepanov (1995) and in accordance with the international taxonomic database The Plant List (www.theplantlist.org). When identifying the species of plants, the 'Keys to Plants of Central Asia' (1968-1993) was used.

The ontogenetic structures of CPs are defined as the ratio in the $\mathrm{CP}$ of individuals of different ontogenetic states. An indi- 


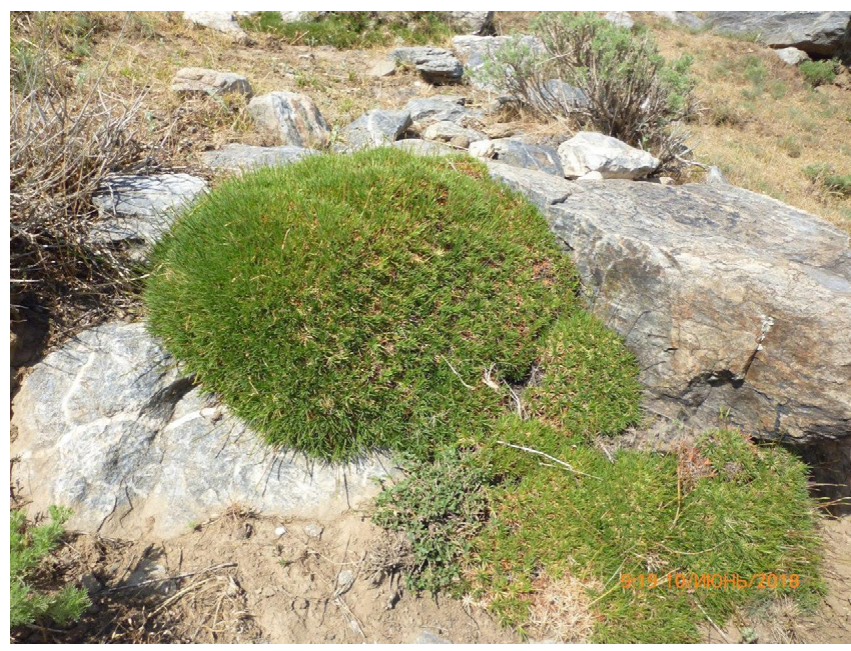

Fig. 2. General view of Acantholimon nuratavicum (June 2018. Photo by V. K. Sharipova).

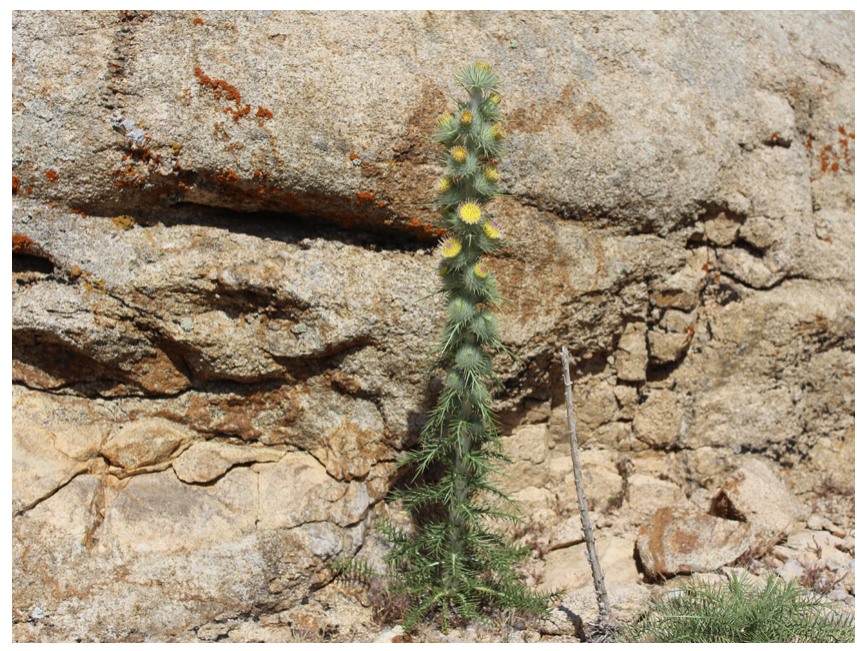

Fig. 3. General view of Cousinia pseudolanata (June 2019. Photo by N. K. Rakhimova).

vidual was accepted as a counting unit. When characterising the population structure, they relied on the concept of a characteristic ontogenetic spectrum (Zaugolnova, 1994). The transects are $10-\mathrm{m}$ long and divided into $1-\mathrm{m}^{2}$ sites. According to the nature of the distribution of ontogenetic groups, four types of spectra are distinguished: left sided, centred, right sided and bimodal. The characteristic spectrum depends on the biological characteristics of the species.

The assessment of the state of populations of rare species was carried out on the basis of ideas about the characteristic ontogenetic spectrum according to the classifications of Uranov and Smirnova (1969).

\section{Study area}

In the course of field studies organised in 2017-2019 in the Navoi region, along with other rare species, two CPs of Acantholi-

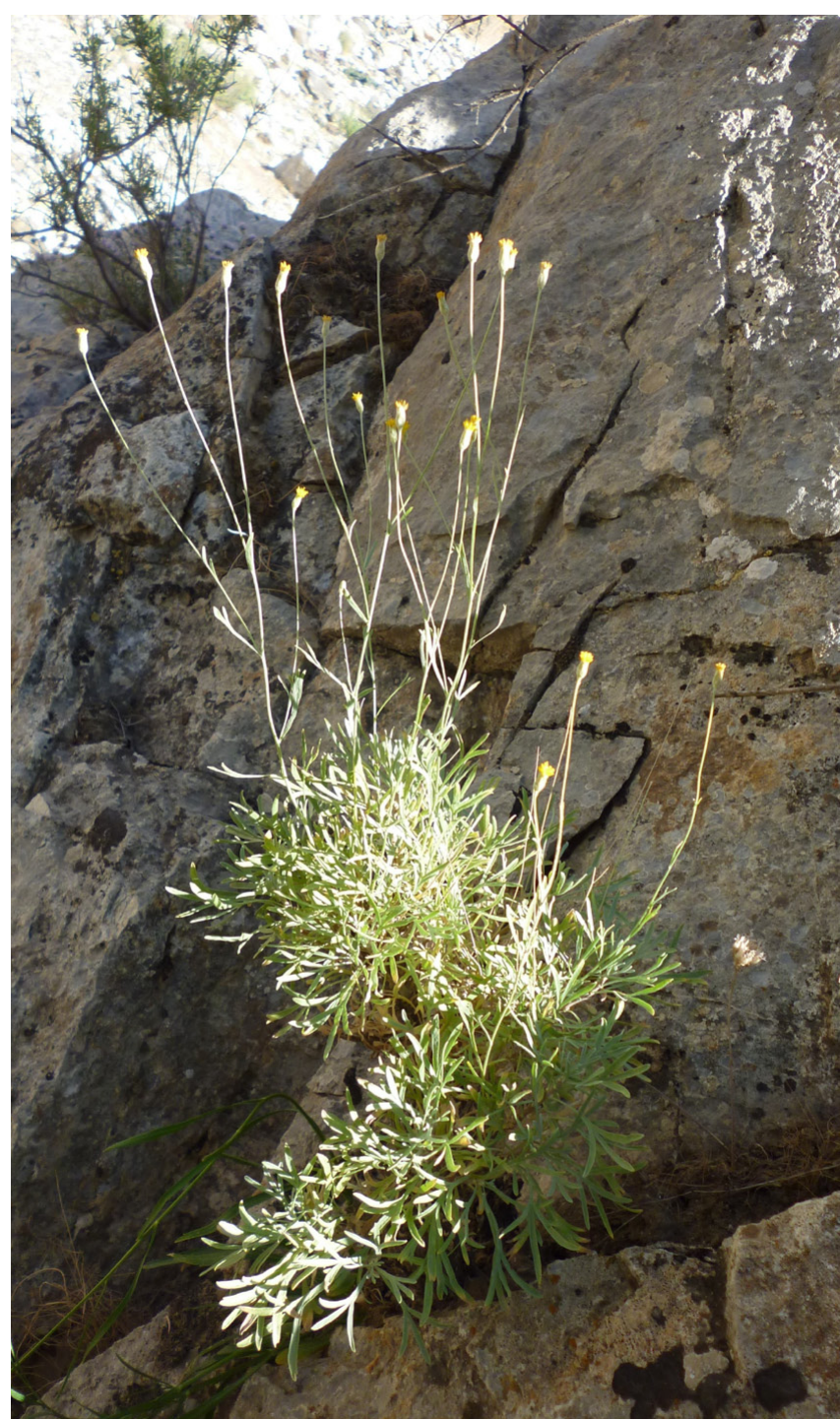

Fig. 4. General view of Lepidolopha nuratavica (June 2018. Photo by N. K. Rakhimova).

mon nuratavicum, Cousinia pseudolanata, Lepidolopha nuratavica, included in the Red Book of Uzbekistan, were studied (Figs $1-4)$. Below is a brief description of the place of growth of these CPs (Table 1).

Navoi region is located in the central part of the Republic of Uzbekistan. In physical and geographical terms, it includes most of the Kyzylkum desert (in most of the remnant lowlands), the western half of Lake Aydarkul, the western part of the Nurata and Zirabulak-Ziadin mountains, part of the valley of the Zeravshan river in its lower reaches and a small area in the northwest of Karnabchul. Navoi region is rich in minerals and is one of the most industrially developed regions of the Republic of Uzbekistan. There are large mining, machine-building, chemical enterprises and enterprises of other industries. There are no nature reserves or national parks within the region; only the Sentyabsay and Sobsay tracts on the Nuratau ridge belong to the protected zone of the Nurata nature reserve (Tojibaev et al., 2019). 
Table 1. Characteristics of plant communities of the studied species.

\begin{tabular}{|c|c|c|c|c|c|c|}
\hline $\begin{array}{l}\text { № } \\
\text { CP }\end{array}$ & Geographic locations CP & The soil & $\begin{array}{l}\text { Geographical } \\
\text { coordinates }\end{array}$ & Plant communities & $\begin{array}{l}\text { Number of } \\
\text { species in the } \\
\text { community }\end{array}$ & $\begin{array}{c}\text { Total } \\
\text { projective } \\
\text { cover, } \%\end{array}$ \\
\hline \multicolumn{7}{|c|}{ Acantholimon nuratavicum } \\
\hline 1 & $\begin{array}{l}\text { Northern slope } \\
\text { of the Nuratau ridge } \\
\text { in the vicinity of the Sob } \\
\text { pass }\end{array}$ & $\begin{array}{l}\text { Rough skeletal } \\
\text { brown, slightly } \\
\text { carbonated }\end{array}$ & $\begin{array}{l}40^{\circ} 67^{`} 37^{\prime \prime} \\
66^{\circ} 41^{`} 84^{“}\end{array}$ & $\begin{array}{c}\text { Artemisia tenuisecta- } \\
\text { Carex pachystylis- } \\
\text { Ferula ovina, Poa } \\
\text { bulbosa }\end{array}$ & 12 & 35 \\
\hline 2 & $\begin{array}{l}\text { Between Sob Pass } \\
\text { and Fazilman Lake }\end{array}$ & $\begin{array}{l}\text { Brown, } \\
\text { slightly } \\
\text { carbonated }\end{array}$ & $\begin{array}{l}40^{\circ} 67^{\prime} 85^{\prime \prime} \\
66^{\circ} 33^{\prime} 98^{\prime \prime}\end{array}$ & $\begin{array}{c}\text { Festuca valesiaca- } \\
\text { Artemisia tenuisecta }\end{array}$ & 9 & 40 \\
\hline \multicolumn{7}{|c|}{ Lepidolopha nuratavica } \\
\hline 1 & $10 \mathrm{~km}$ west of Chuya village & $\begin{array}{l}\text { Steep rocky } \\
\text { slope of } \\
\text { eastern } \\
\text { exposure }\end{array}$ & $\begin{array}{l}40^{\circ} 43^{\prime} 05^{\prime \prime} \\
66^{\circ} 02^{\prime} 79^{\prime \prime}\end{array}$ & $\begin{array}{l}\text { Prunus bucharica- } \\
\text { Lepidolpha nuratavica, } \\
\text { Artemisia tenuisecta, } \\
\text { Ferula penninervis }\end{array}$ & 14 & 17 \\
\hline 2 & $2.7 \mathrm{~km}$ west of the first $\mathrm{CP}$ & $\begin{array}{l}\text { Western } \\
\text { exposure steep } \\
\text { rocky slope }\end{array}$ & $\begin{array}{l}40^{\circ} 41^{\prime} 86^{\prime \prime} \\
66^{\circ} 02^{\prime} 01^{\prime \prime}\end{array}$ & $\begin{array}{l}\text { Prunus spinosissima, } \\
\text { Pr. bucharica-Crambe } \\
\text { cordifolia, Festuca } \\
\text { ovina, Poa bulbosa }\end{array}$ & 18 & 35 \\
\hline \multicolumn{7}{|c|}{ Cousinia pseudolanata } \\
\hline 1 & $\begin{array}{l}\text { Nurata mountains (Langar } \\
\text { village) along the road }\end{array}$ & Stony-gravelly & $\begin{array}{l}40^{\circ} 40^{\prime} 40^{\prime \prime} \\
65^{\circ} 93^{\prime} 92^{\prime \prime}\end{array}$ & $\begin{array}{c}\text { Perovskia } \\
\text { scrophularifolia- } \\
\text { Cousiniapseudolanata }\end{array}$ & 9 & 10 \\
\hline 2 & $\begin{array}{l}\text { Nurata mountains } \\
\text { (Langar village) }\end{array}$ & $\begin{array}{l}\text { Steep rocky- } \\
\text { gravelly slope }\end{array}$ & $\begin{array}{l}40^{\circ} 42^{\prime} 46^{\prime \prime} \\
65^{\circ} 95^{\prime} 78^{\prime \prime}\end{array}$ & $\begin{array}{c}\text { Convolvulus hamadae, } \\
\text { Po. bulbosa, Polygonum } \\
\text { aviculare }\end{array}$ & 7 & 3 \\
\hline
\end{tabular}

Note: CP - coenopopulation.

According to its natural and climatic conditions, the territory of Navoi region belongs to the zone of sharply continental arid climate, in which the summers are hot and dry and winters are moderately cold with frosts of medium strength. The average January temperature is from $0{ }^{\circ} \mathrm{C}$ in the south of the region to $-6{ }^{\circ} \mathrm{C}$ in the north; the average July temperature is from +28 to $+30{ }^{\circ} \mathrm{C}$; the average annual air temperature is about +13 ${ }^{\circ} \mathrm{C}$ in the north of the region (Uchkuduk) and $+15.6{ }^{\circ} \mathrm{C}$ in the south (Navoi); the average annual precipitation is from $121 \mathrm{~mm}$ (Uchkuduk) and less in the northern, desert part of the region up to $338 \mathrm{~mm}$ per year in the south, in the Zeravshan valley (Navoi) (https://ru.climate-data.org; Williams, Konovalov, 2008).

\section{Results and discussion}

We have described two CPs of Acantholimon nuratavicum growing on the Nurata ridge. The first of the studied CPs grows on the northern slope of the Nuratau Ridge in the vicinity of the Sob pass, as part of Artemisia tenuisecta-Carex pachystylis-Ferula ovina, Poa bulbosa community, on a rough skeletal brown, slightly carbonated soil. The total projective herbage cover is $35 \%$. Geological exploration is underway on the described area. The floristic composition of the community is not rich and consists of 12 species of vascular plants. The dominant species are Artemisia tenuisecta Nevski, Carex pachystylis J. Gay and Ferula ovina Boiss. The second CP is located on a fine earth, strongly washed away brown, low-carbonate soil on a gentle plateau between the Sob pass and Lake Fazilman. Festuca valesiaca Gaudin and Artemisia tenuisecta Nevski prevail in the Festuca valesiacaArtemisia tenuisecta community, where this CP was studied. The floristic composition of the community is not rich and consists of nine species of vascular plants. The total projective cover of the herbage reaches $40 \%$, and the projective cover of Acantholimon nuratavicum in this community is $3 \%$.

The first of the studied CP Lepidolopha nuratavica is located about $10 \mathrm{~km}$ west of the Chuya village on a steep rocky slope of the eastern exposure as a part of Prunus bucharica-Lepidolopha nuratavica, Artemisia tenuisecta, Ferula penninervis community. The total projective cover of vegetation is $17 \%$ and that of Lepidolopha nuratavica is $1 \%$. The floristic composition of the community consists of 14 species of vascular plants, most of which (57\%) are perennials. The dominant species are Prunus bucharica (Korsh.) B. Fedtsch. ex Rehder and Atraphaxis seravschanica Pavlov. The second CP Lepidolopha nuratavica grows on a steep rocky slope of western exposure as part of Prunus spinosissima, Pr. bucharica-Crambe cordifolia, Ferula ovina, Poa bulbosa community. This CP is located approximately $2.7 \mathrm{~km}$ west of the first $\mathrm{CP}$. The total projective cover of vegetation is $35 \%$, and the projective cover of the studied species in this community reaches $2 \%$. The floristic composition of the community consists of 18 
Table 2. Distribution of individuals by age groups.

\begin{tabular}{|c|c|c|c|c|c|c|c|c|}
\hline \multirow[t]{3}{*}{ № $\mathbf{C P}$} & \multicolumn{8}{|c|}{ Age distribution, \% } \\
\hline & \multicolumn{8}{|c|}{ Acantholimon nuratavicum } \\
\hline & j & $\operatorname{Im}$ & $\mathrm{V}$ & g1 & $\mathrm{g} 2$ & g3 & ss & s \\
\hline 1 & 0 & 0 & 0 & 27.2 & 45.4 & 18.1 & 0 & 9.0 \\
\hline 2 & 0 & 0 & 0 & 30.3 & 57.5 & 9.0 & 0 & 3.0 \\
\hline \multicolumn{9}{|c|}{ Lepidolopha nuratavica } \\
\hline 1 & 0 & 0 & 6.6 & 22.2 & 42.2 & 20.0 & 0 & 8.8 \\
\hline 2 & 0 & 0 & 10.0 & 42.5 & 37.5 & 7.5 & 0 & 2.5 \\
\hline \multicolumn{9}{|c|}{ Cousinia pseudolanata } \\
\hline 1 & 0 & 40.8 & 44.8 & 4.0 & 6.1 & 2.0 & 2.0 & 0 \\
\hline 2 & 0 & 33.3 & 25.0 & 8.3 & 16.6 & 0 & 8.3 & 8.3 \\
\hline
\end{tabular}

Notes: j - juvenile; im - immature; $\mathrm{v}$ - virginal; g1 - young generative; g2 - middle-aged generative; g3 - aging generative; $\mathrm{s}$ - senile.

species of vascular plants; among them, as in the first CP, perennials predominate. The dominant species are Prunus spinosissima (Bunge) Franch. and Pr. bucharica (Korsh.) B. Fedtsch. ex Rehder.

During the field research, two CPs of Cousinia pseudolanata were studied. Both CPs grow in the Nurata mountains (Langar village). The first $\mathrm{CP}$ of $C$. pseudolanata was studied along the road as part of Perovskia scrophulariifolia-Cousinia pseudolanata community on stony-gravelly soil. The total projective herbage cover is $10 \%$. The share of the investigated species does not exceed $1 \%$. The floristic composition of the community is not rich and consists of nine species of vascular plants. The dominant species are Perovskia scrophulariifolia Bunge and Cousinia pseudolanata Popov ex Tscherneva. The second CP of C. pseudolanata grows in a petrophytic group. This $\mathrm{CP}$ was studied closer to the settlement. The total projective cover of the herbage does not exceed 3\%. The floristic composition of the group consists of seven species of vascular plants.

\section{Ontogenetic structure of CPs Acantholimon nuratavicum}

The ontogenetic structure of CPs of the studied species has not been studied before. According to Uranov and Smirnova (1969), both studied $A$. nuratavicum $\mathrm{CPs}$ are normal, but incomplete (Table 2, Fig. 5). Self-maintenance of CPs occurs exclusively through the seed route. Based on the peculiarities of the biology of the species, low seed germination, rapid transition to flowering and slow development rates of individuals in a mature generative state, the characteristic spectrum of CPs of this species will be a centred type with a peak on middle-aged generative individuals. The ontogenetic spectrum of CPs of the centred type reflects the characteristic ontogenetic spectrum of this species.

A centred spectrum is formed in shrub plants with a long lifespan of individuals in a middle-aged ontogenetic state, their least elimination and difficult seed germination (Zaugolnova et al., 1993). The peak falls on middle-aged generative individuals. The share of mature generative individuals in the $\mathrm{CP}$ is $45.4-57.5 \%$. The high proportion of this age group in the CP is associated with the longest duration of this ontogenetic state. The absence of all age groups on the left side of the spectrum is probably associated with low seed germination, irregular seed

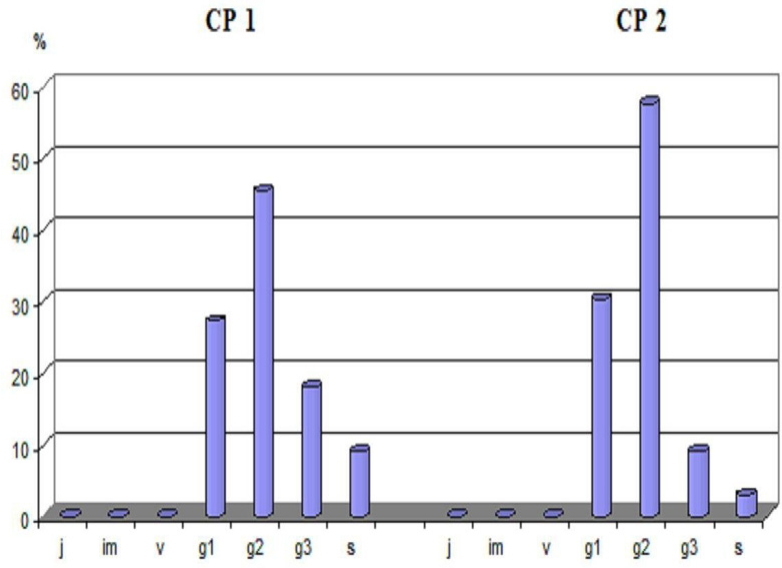

Fig. 5. Ontogenetic spectra of coenopopulations Acantholimon nuratavicum.

Notes: $\mathrm{j}$ - juvenile; im - immature; $\mathrm{v}$ - virginal; g1 - young generative; g2 - middle-aged generative; g3 - aging generative; $\mathrm{s}$ - senile, \%.

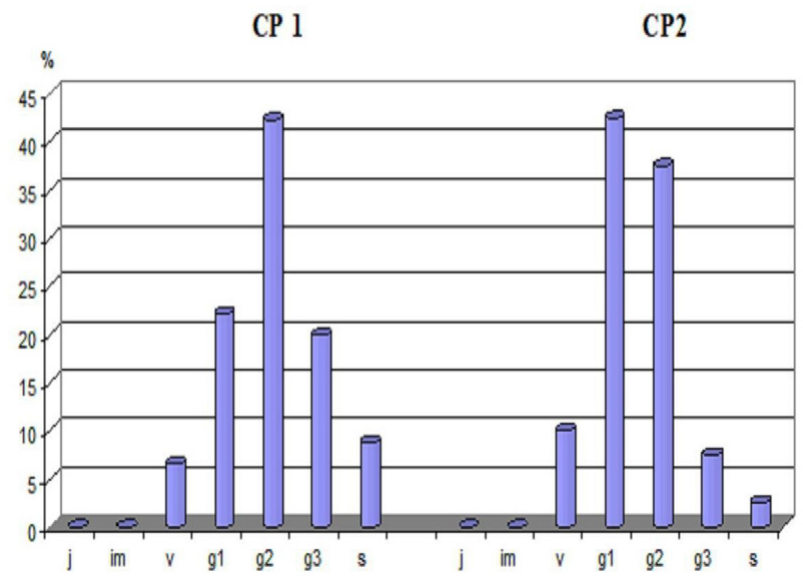

Fig. 6. Ontogenetic spectra of coenopopulations Lepidolopha nuratavica. 


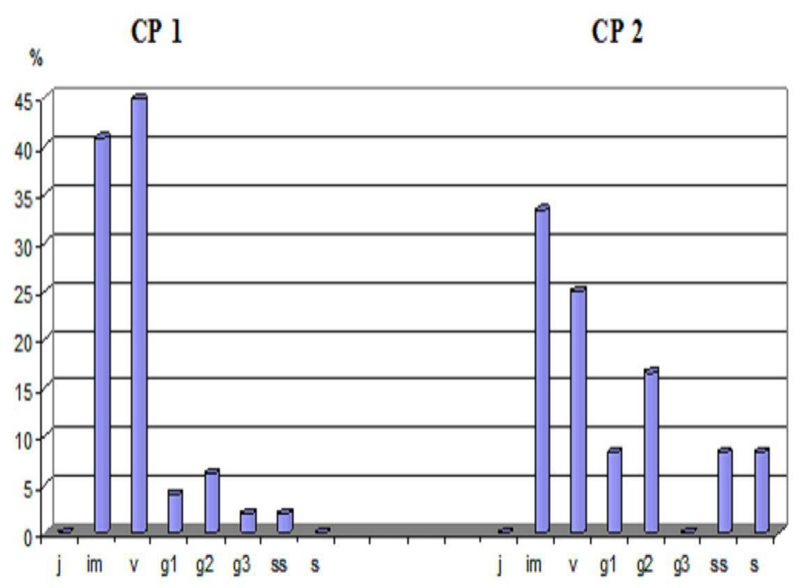

Fig. 7. Ontogenetic spectra of coenopopulations of Cousinia pseudolanata.

renewal and intensive grazing. Note that CPs were described in the area where the pasture load is several times higher than the norm. The minimal participation of old individuals in the $\mathrm{CP}$ is associated with the loss of most plants in the old generative state.

\section{Ontogenetic structure of CPs Lepidolopha nuratavica}

Both CPs of L. nuratavica lack juvenile and immature individuals (Fig. 6). Both CPs grow on steep rocky slopes, on outcrops of bedrock, as a result of which spring torrential rains and mudflows often wash away young immature plants. Cattle grazing also has a negative impact on both CPs. The ontogenetic structure of the studied CPs has two types of spectrum: centred (CP 1) and left sided (CP 2). The first CP is dominated by middle-aged generative individuals. Their percentage in the CPU is $42.2 \%$. Elimination of the young fraction and a gradual increase in the lifespan of individuals in the generative period leads to the predominance of middleaged generative individuals in this $\mathrm{CP}$. The ontogenetic structure of this $\mathrm{CP}$ coincides with the characteristic spectrum. The second $\mathrm{CP}$ is dominated by young generative individuals. A similar variant of the spectrum was formed on a shrub-covered slope of the western exposure. The comparatively perceptible moisture supply at this exposition contributes to the accelerated rate of development of the pregenerative fractions of plants. The ontogenetic structure of this CP does not coincide with the characteristic spectrum.

\section{Ontogenetic structure of CPs Cousinia pseudolanata}

The ontogenetic structure of C. pseudolanata CPs has not been previously studied. The ontogenetic structure of two CPs of $C$. pseudolanata growing on the Nurata ridge was studied. According to Uranov and Smirnova (1969), the studied CPs are normal and incomplete (Fig. 7). C. pseudolanata is characterised by the seed mode of self-maintenance of CPs, a short pregenerative period and a long stay in a middle-aged generative state.

The ontogenetic structure of the studied CP has one type of spectrum: left sided. In both CPs, individuals of the pregen- erative period predominate and the absolute maximum falls on immature and virginal individuals. Their percentage in the $\mathrm{CP}$ ranges from $25.0 \%$ to $44.8 \%$. The low value of the share of generative individuals in the $\mathrm{CP}$ is associated with the recreational process; $\mathrm{CP}$ is subject to intense anthropogenic load. Slightly more than $8 \%$ of individuals belong to the old fractions of plants. The ontogenetic structure of CPs does not coincide with the characteristic spectrum. The predominance in CPs of individuals of the pregenerative period is associated with the rapid development of the young fraction of plants and the elimination of immature young individuals during spring atmospheric precipitation. The minimal participation of old individuals in CPs is associated with the loss of most individuals in the old generative state.

\section{Conclusion}

Based on a comparison of real spectra with theoretically established spectra, the state of the populations of the studied species was estimated. The studied CPs growing on the Nuratau and Aktau ridges are normal and incomplete. During the study period, individuals of Acantholimon nuratavicum were in a depressed state, which is associated with the ecological and phytocoenotic growing conditions and strong anthropogenic load.

The studied Lepidolopha nuratavica CPs during the observation period are in an unsatisfactory state. Individuals do not go through all stages of ontogenesis. The absence of certain ontogenetic groups in CPs is associated with the ecological conditions of growth and anthropogenic pressure.

The studied CPs of Cousinia pseudolanata in different ecological-phytocoenotic conditions are satisfactory. The proportion of generative individuals in the right part of the spectrum is low, the ontogenetic spectrum of the studied CP does not coincide with the characteristic one, and they differ due to the ecological-phytocoenotic growing conditions and different degrees of anthropogenic load.

Both anthropogenic and natural factors pose a threat to the studied populations: overgrazing, extreme ecological conditions of the habitat, climate change and desertification.

\section{Acknowledgements}

This work was carried out as a part of the project P3-20170919165 'Cadastre of rare and endangered species of vascular plants of the $\mathrm{Na}$ voi and Bukhara regions'.

\section{References}

Akhmedov, A.K., Cheremushkina, V.A. \& Shomurodov H.F. (2015). Ontogeny and ontogenetic structure of coenopopulations of Lagochilus gypsoseus Vved. (Lamiaceae) in Kyzylkum, Uzbekistan. The Flora of Asian Russia, 2(18), 32-38.

Bastian, O., Cudlín, P., Pechanec, V., Brzoska, P., Štěrbová, L., Včeláková, R., Purkyt, J. \& Grunewald K. (2020). Assessments of biodiversity and habitat services in cities - exemplified by Dresden (Germany) and Liberec (Czech Republic). Ekológia (Bratislava), 39(2), 174-189. DOI: 10.2478/ eko-2020-0013.

Cheremushkina, V.A. \& Astashenkov A.Yu. (2014). Morphogenesis and ontogenetic structure of the coenopopulation of Nepeta podostachys (Lamiaceae) in the conditions of Tajikistan. The Flora of Asian Russia, 3(15), $32-38$.

Corlett, R.T. (2016). Plant diversity in a changing world: Status, trends, and conservation needs. Plant Diversity, 38(1), 10-16. DOI: 10.1016/j. pld.2016.01.001. 
Czerepanov, S.K. (1995). Vascular plants of Russia and adjacent states (the Former USSR). Cambridge: Cambridge University Press.

Denisova, G.R. \& Cheremushkina V.A. (2009). Ontogenetic structure of coenopopulations of Dracocephalum grandiflorum L. (Lamiaceae) in Siberia. The Flora of Asian Russia, 1(3), 83-87.

Esanov, H.K. \& Sharipova V.K. (2020). Addition to the flora of Bukhara region (Uzbekistan). Journal of Turczaninowia, 23(1), 126-128. DOI 10.14258/turczaninowia.23.1.13.

Field geobotany (1964). Moscow-Leningrad: Academy of Sciences of the USSR.

Ishbirdin, A.R. \& Ishmuratova M.M. (2009). Some directions and results of research of rare species of flora of the Republic of Bashkortostan. Bulletin of the Udmurt University, 1, 59-72.

Keys to Plants of Central Asia (1968-1993). In 10 volumes. Tashkent: Fan.

Klimantová, A. (2020). Ecological evaluation of grassland vegetation in Hodrušská hornatina highland. Ekológia (Bratislava), 39(3), 236-249. DOI: 10.2478/eko-2020-0018.

Li, W. \& Zhang G.-Fu. (2015). Population structure and spatial pattern of the endemic and endangered subtropical tree Parrotia subaequalis (Hamamelidaceaea). Flora, 212, 10-18. DOI: 10.1016/j.flora.2015.02.002.

Rakhimova, T. Rakhimova, N.K., Shomurodov, Kh.F. \& Abduraimov O.S (2020). Ontogenetic structure of rare plant spesies on the Usturt Plateau in Uzbekistan. Journal of Arid Ecosystems, 10(3), 238-243. DOI $10.1134 /$ S2079096120030075

Saribaeva, Sh.U. \& Shomurodov H.F. (2017). Actual state of coenopopulations of Astragalus centralis Sheld. Under condition of Kuldzhuktau ridge (Kyzylkum desert). Journal of Arid Ecosystems, 7(4), 265-270. DOI: 10.1134 / S2079096117040096.

Shomurodov, H.F. \& Adilov B.A. (2019). Current State of the Flora of Vozrozhdeniya Island (Uzbekistan). Journal of Arid Ecosystems, 9(2), 97103. DOI:10.1134 / S2079096119020100.

Shomurodov, H.F. \& Khasanov F.O. (2014). Fodder plants of the Kyzyl Kum Desert. Journal of Arid Ecosystems, 4(3), 208-213. DOI: 10.1134/ S2079096114030093.

Shomurodov, H.F., Khuzhanazarov, U., Beshko, N.Yu., Akhmadalieva, B. \& Sharipova V.K. (2017). A demographic structure of populations of Salvia lilacinocoerulea Nevski, a rare species endemic to the Western PamirAlay (Uzbekistan, Turkmenistan). American Journal of Plant Sciences, 8, 1411-1422. DOI: 10.4236/ajps.2017.86096.
Shomurodov, H.F., Saribaeva, Sh.U. \& Akhmedov A. (2015). Distribution Pattern and Modern Status of Rare Plant Specieson the Ustyurt Plateau in Uzbekistan. Journal of Arid Ecosystems, 5(4), 261-267. DOI: 10.1134 / S2079096115040125.

The Plant List. URL: www.theplantlist.org.

Tojibaev, K.Sh., Beshko, N.Yu., Shomurodov, H.F., Abduraimov, O.S., Adilov, B.A., Akhmedov, A.K., Rakhimova, T., Rakhimova, N.K., Saribaeva, Sh.U., Khaitov, R.Sh. \& Sharipova V.K. (2019). Uzbekistan flora cadastre: Navoi region. Tashkent: Fan.

Uranov, A.A. \& Smirnova O.V. (1969). Classification and main features of the development of populations of perennial plants. Bulletin MOIP, 74(2), 119-134.

Volis, S., Zhang, Y.H., Dorman, M. \& Blecher M. (2015). Iris atrofusca genetic and phenotypic variation, the role of habitat-specific selection in this variation structuring and conservation implications using quasi in situ guidelines. Isr. J. Plant Sci., 63(4), 347-354. DOI 10.1080/07929978.2015.1042308.

William, M.W. \& Konovalov V.G. (2008). Central Asia temperature and precipitation data, 1879-2003 [list the dates of the data used]. Boulder, Colorado: USA National Snow and Ice Data Center. DOI: 10.7265/ N5NK3BZ8.

Yang, M. (2013). The current situation and protection of China Rare and Endangered See Plants. International Journal of Enviromental Protection, 3(5), 29-34.

Zaugolnova, L.B. (1994). Population structure of seed plants and problems of their monitoring. St. Petersburg.

Zaugolnova, L.B., Smirnova, O.V., Komarov, A.S. \& Khanina P.G. (1993) Monitoring phytopopulations. Advances in Modern Biology, 113(4), $402-414$. 